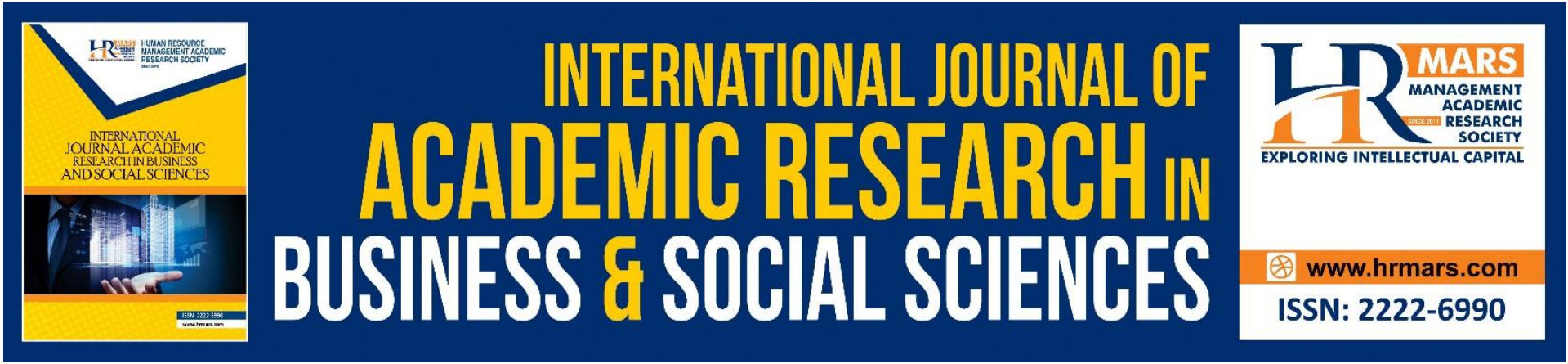

\title{
Human Capital Investment and Economic Growth: A Study on ASEAN Countries
}

Sharmila Thinagar, Mohd Khairi Ismail, Low Ai Vy, Aainaa Amirah Haron

To Link this Article: http://dx.doi.org/10.6007/IJARBSS/v11-i18/11425 DOI:10.6007/IJARBSS/v11-i18/11425

Received: 07 August 2021, Revised: 30 August 2021, Accepted: 20 September 2021

Published Online: 10 October 2021

In-Text Citation: (Thinagar et al., 2021)

To Cite this Article: Thinagar, S., Ismail, M. K., Vy, L. A., \& Haron, A. A. (2021). Human Capital Investment and Economic Growth: A Study on ASEAN Countries. International Journal of Academic Research in Business and Social Sciences, 11(18), 12-24.

\section{Copyright: (C) 2021 The Author(s)}

Published by Human Resource Management Academic Research Society (www.hrmars.com)

This article is published under the Creative Commons Attribution (CC BY 4.0) license. Anyone may reproduce, distribute, translate and create derivative works of this article (for both commercial and non-commercial purposes), subject to full attribution to the original publication and authors. The full terms of this license may be seen

at: http://creativecommons.org/licences/by/4.0/legalcode

Special Issue Title: TiBECVII 2021, 2021, Pg. 12 - 24

Full Terms \& Conditions of access and use can be found at http://hrmars.com/index.php/pages/detail/publication-ethics 


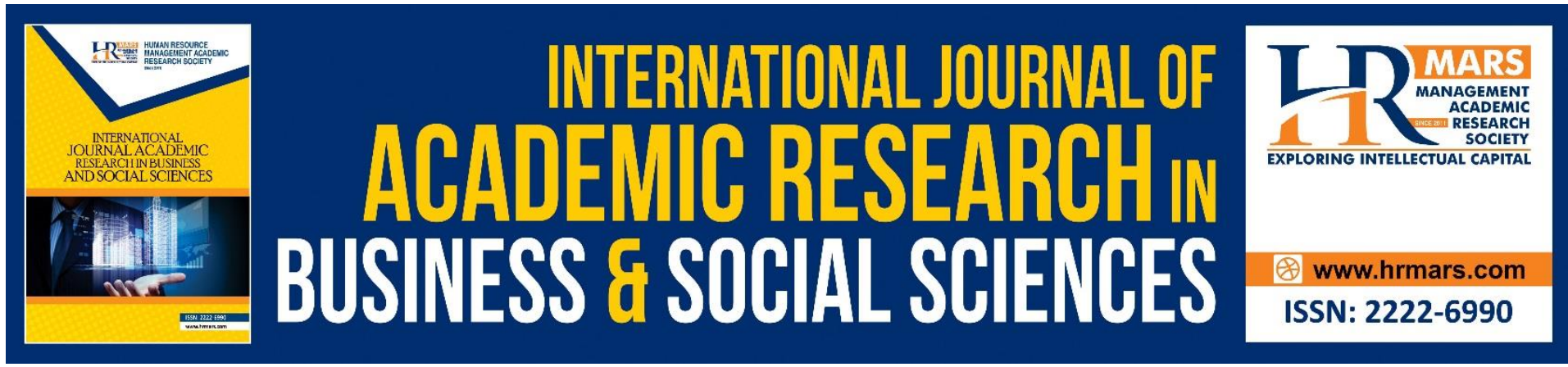

\title{
Human Capital Investment and Economic Growth: A Study on ASEAN Countries
}

\author{
${ }^{1}$ Sharmila Thinagar, ${ }^{2}$ Mohd Khairi Ismail, ${ }^{3}$ Low Ai Vy, ${ }^{3}$ Aainaa \\ Amirah Haron \\ ${ }^{1}$ Faculty of Business \& Management, QUEST International University, ${ }^{2}$ Faculty of Business \& \\ Management, Universiti Teknologi MARA, ${ }^{3}$ Faculty of Economics \& Management, Universiti \\ Kebangsaan Malaysia \\ Email: khairiismail@uitm.edu.my
}

\begin{abstract}
Using yearly data from January 1995 to December 2014, this paper explores the relationship between GDP per capita, education expenditure, health expenditure, and gross capital formation in Indonesia, Malaysia, the Philippines, and Thailand. In this paper, we used panel co-integration (Pedroni Panel Co-integration, Kao Residual Co-integration test, and Johansen Fisher Co-integration test), panel fully modified ordinary least squares (FMOLS), and granger causality. From the empirical result, we discovered that: 1 ) variables are co-integrated in the long run; 2) FMOLS results show that health spending and gross capital accumulation have a positive effect on economic growth; and 3) granger causality results show that a few of the variables have bidirectional and unidirectional causality.
\end{abstract}

Keywords: Co-integration, Gross Domestic Product, Education Expenditure, Health Expenditure; Gross Capital Formation.

\section{Introduction}

Some Asian developing countries' economies face specific challenges in the health and education sectors because these countries do not prioritise these sectors in order to achieve high growth rates and sustain their status as high-income countries. Malaysia, Indonesia, Thailand, and the Philippines, for example, witnessed rapid growth rates in the 1980s and early 1990s, but not enough to reach the high-income benchmark. Malaysia and Thailand are upper middle-income countries, while Indonesia and the Philippines are middle-income countries (World Bank, 2016). According to the World Economic Forum's Human Capital Index $(\mathrm{HCl})$, East Asia and Pacific countries' scores are in the middle of the pack, with an overall average ranking of 69.75. By reviewing the ASEAN country scope, Table 1 below reported the $\mathrm{HCl}$ rank and $\mathrm{HCl}$ value of the top 4 ASEAN countries that have experienced rapid economic growth but have not yet achieved high-income status. 
Table 1: Human Capital Index Rank and Score of the 4 ASEAN Countries

\begin{tabular}{|l|c|c|}
\hline \multicolumn{1}{|c|}{2018} & $\mathrm{HCl} \mathrm{Score}$ & $\mathrm{HCl}$ Rank \\
\hline Malaysia & 0.62 & 55 \\
\hline Thailand & 0.60 & 65 \\
\hline Indonesia & 0.53 & 87 \\
\hline Philippines & 0.55 & 84 \\
\hline
\end{tabular}

(Source: World Bank, 2019)

The level of government spending on education, health, and other investments determines a country's economic growth. Human capital has become a focal point in explaining a country's economic growth since the introduction of endogenous growth theory by Uzawa (1965); Robert (1988); Romer (1990). From a theoretical standpoint, human capital is an essential component that includes expertise, capacity, and abilities that can explain economic development, increase productivity across various channels, and thus stimulate a country's economic growth (Neeliah and Seetanah, 2015). Aside from that, human capital shows a positive opportunity and long-term driver in achieving growth and stable production.

Human capital is the primary development factor in increasing output at the micro level, and it is expected to contribute to long-term economic growth. Human capital investment is an essential expenditure that should be prioritised in every country because it helps to improve the quality of human resources. According to the World Bank (1993), one of the significant reasons for East Asian economic growth between 1960 and 1990 was investment in primary and secondary education. A few studies have been conducted that highlight the importance of health as a component of human resources. Developed countries, such as the United States, devote a significant portion of their GDP (17.1\% of GDP) to health care because they assume that it is the primary driver of economic activity and growth. As a result, ASEAN countries should aim to increase government healthcare spending. This is particularly concerning for ASEAN countries, as many questions have been raised about the situation. First, is there a connection between the pattern of human capital investments (education and health spending) and the rate of economic growth in the 4-ASEAN countries? Second, do physical resources and labour lead to economic development in conjunction with human capital investments?

As a result, empirical research into how physical resources, human capital expenditure, and labour relate to the economic growth of the 4-ASEAN selected countries is needed. The remainder of the paper is structured as follows. The second section provides a brief overview of the literature on the theoretical and empirical relationship between gross capital formation, education spending, health spending and economic health. The third section of this paper explains the methods and describes the data used in the empirical study, followed by the fourth section, which describes the empirical results and explores the key findings. Finally, the fifth section summarises the empirical analysis and its policy consequences. In general, we examine the long-run relationship between physical resources, labour, human capital expenditure, and GDP growth in 4-ASEAN countries: Malaysia, Indonesia, Thailand, and the Philippines. This thesis has three specific goals:

I. To determine co-integration relationship between the dependent variable (GDP per capita) and the independent variables (education expenditure, health expenditure, gross capital formation and labour),

II. To estimate the long-term co-integration coefficients,

III. To determine whether the direction of causality between the variables. 


\section{Literature Review}

Academicians and economists all over the world have conducted numerous empirical studies on human capital investment and economic growth. Most studies show that government spending on specific sectors, such as education, health, and labour, has an impact on economic growth (Mekdad et al., 2014; Tatoglu, 2011; Agbola, 2013; Yildirim et al., 2020). All these factors can be viewed as investments in human development. Investments are required to improve a country's quality of life and maintain its economic growth. The subsections that follow clarify the factors that are considered as an investment in human development:

\section{Education}

Several papers used education spending as an educational proxy to study the relationship between education and economic growth (Dzubaidi et al., 2013; Mercan, 2013; Mekdad et al., 2014; Mat et al., 2015; Siddiqui and Rehman, 2016; Oyedokun, 2018). The relation between education and economic growth has been investigated by various researchers using different methods. Dzubaidi et al (2013) conducted an interesting study using the Two-Stage Least Squares (2SLS) method and the simultaneous equation model to examine the relationship between government spending in education and human development channel. According to the findings of the study, government spending on education expenditure has a positive relationship with human development.

Mercan (2013) found that education spending in Turkey had a positive long-run impact but a negative short-run effect on economic development. The Autoregressive Distributed Lag (ARDL) was also used by the author, who discovered that there is a bidirectional connection between education spending and economic development. Similarly, Mekdad et al (2014) and Mat et al. (2015) looked at the relationship between human capital investment and economic growth using the Ordinary Least Square (OLS). The two studies have proven that investment in human capital in education has a positive connection to Algeria and Sabah economic development. Siddiqui and Rehman (2016) argue in Asia that primary and secondary education are more important to highlight economic growth variations in East Asia while tertiary and vocational education have had positive effects on South Asia's economic growth. Oyedokun (2018) has recently shown that Nigeria has a long-standing positive link between education expenditure and economic growth through the Granger Causality Test.

\section{Health}

Multiple researches have been argued based on the relationship between health and economic development (Tatoglu, 2011; Elmi and Sadeghi, 2012; Dzubaidi et al., 2013; Mat et al., 2015; Boachie, 2017; Sarpong et al., 2018; Atuahene et al., 2020; Yang, 2020; and Yildirim et al., 2020). Tatoglu (2011); Elmi and Sadeghi (2012) examined the relationship between health expenditures and economic growth in the long and short run using panel error correction models and causality in vector error correction models. Numerous researchers have used the causality in a vector corrections model to identify the direction for causal error and Elmi and Sadeghi (2012) found that there is a bilateral causality between healthcare expenditure and economic growth on the long-term basis but in the short term however, the causes from economic growth to health expenses are only unidirectional. However, the presence of a bidirectional causal relationship between health expenses and economic growth was highlighted in (Sarpong et al., 2018). Studies in Dzubaidi et al (2013) and Mat et al (2015) found positive links between healthcare expenditure and economic growth using a two-stage less square simultaneous equation model. 
Likewise, Boachie (2017) notes that good health stimulates economic growth in both the short and long term. Lately, Yildirim et al (2020) used cluster analysis to divide the 12 OECD countries into two groups: high and low health status. The cluster analysis results indicate that countries with higher health status had no substantial effect on economic growth, while countries with lower health status had a positive impact on economic growth. According to Atuahene et al (2020), economic growth has a negative effect on health spending and there is a clear association between health and economic growth, which is important for economic development. Yang (2020), on the other hand, reports the facts in three categories. For first, when human capital levels are poor, health expenditure is strongly inversely linked to economic development. Second, when human capital is at a medium stage, health spending has a favourable but not statistically important effect on economic development. Third, when the level of human capital is high, the beneficial economic impact of healthcare costs is greatly increased.

\section{Capital}

Furthermore, there are several empirical studies that have been conducted on the relationship between capital and economic development (Bakare and Olubokun 2011; Uneze 2013; Ugochukwu and Chinyere 2013; Agbola 2013; Atuma et al. 2017; Onyinye et al. 2017; Sharma and Mittal 2019; and Rehman et al. 2020). Bakare and Olubokun (2011) used the ordinary least squares method to investigate the relationship between capital and economic growth in Nigeria. According to the findings, there is a direct relationship between capital and gross domestic output in Nigeria. Similarly, Ugochukwu and Chinyere (2013) used VARs to analyze the effects of capital formation on economic development in Nigeria, and the evidence indicates that capital formation has a positive effect on economic growth. Similarly, Atuma et al (2017) discovered that gross foxed capital accumulation induces economic development in Nigeria.

In addition, Uneze (2013) looked through panel cointegration and causality on the causal of capital formation and economic growth in sub-Saharan African countries and there is evidence of a bidirectional causality that shows that higher economic growth leads and reverse to greater capital formation. Agbola (2013) investigated whether human capital limits the effect of foreign direct investment and remittances on economic growth in Ghana using Fully Modified Ordinary Least Squares (FMOLS). The findings indicate that private investment and economic growth in Ghana have a negative relationship. Using the VECM, Onyinye et al. (2017) discovered that gross capital formation has a favorable but negligible effect on real gross domestic product, while Sharma and Mittal (2019); Rehman et al (2020) discovered that GDP is positively influenced by gross capital formation.

\section{Labour}

Several researchers examined the relationship between investment in human capital and economic growth, and labour force involvement is a variable in the determination of the connection between human capital and economic growth (Mushtaq et al., 2013; Shahid, 2014; Maitra, 2016; Osiobe, 2020; Karambakuwa et al., 2020). Mushtaq et al (2013), using Autoregressive Distributed Lag (ARDL), examined the impact of health on the change in laborforce participation and showed that health expenditure, gross capital creation, population and secondary school enrolment were statistically important to Granger-caused labour force participation. The study conducted by Shahid (2014) shows a method used to examine the effects of labor force participation and gross fixed capital information on economic growth by 
Johansen cointegration and the VECM. The results indicate that the link between the participation of labour forces and economic growth exists for a long run.

Similar vein, Maitra (2016) discovered that human capital investment and jobs lead to increased economic development. However, according to Osiobe (2020), there is no clear causal link between human capital and real GDP. Likewise, Karambakuwa et al (2020) discovered that human capital has an insignificant impact on economic development.

\section{Data and Methodology}

The relationship between GDP per capita, education spending, health spending, gross capital formation, and labour force participation is investigated in this paper. Government education and health spending are examples of human capital investment, while gross capital formation is an example of physical capital and secondary school enrolment is an example of labour. All the data used in this paper were obtained from the World Bank. The data used in this analysis spans a period of 20 years, from 1995 to 2014, and includes four ASEAN countries. The countries chosen for this paper were Indonesia, Malaysia, the Philippines, and Thailand.

The macroeconomic model, which is the augmented Solow Model, can be used to estimate how the components of human capital expenditure, physical capital, and labour influence economic development.

The following are the Solow model formulae:

$$
Y=F(K, L)
$$

Since human capital has been injected into the sample, the augmented Solow model would be:

$$
Y=F(K, H, L)
$$

Where $\mathrm{Y}$ represents GDP per capita, $\mathrm{K}$ represents gross capital formation, $\mathrm{H}$ represents human capital (education and health spending), and L represents labour rate participation.

The following is an expression of the model used in this paper:

$$
\begin{aligned}
& \operatorname{lnGDP}_{i t}=\beta_{0}+\beta_{1} \text { lneducation }_{i t}+\beta_{2} \text { lnhealth }_{i t}+\beta_{3} \text { lngross }_{i t}+\beta_{4} \text { lnlabour }_{i t}+\mu_{i t} \\
& \text { Where; } \\
& \text { GDP = gross domestic product (GDP) per capita }- \text { Proxy for } \mathrm{Y} \\
& \text { education = education expenditure }- \text { Proxy for human capital } \\
& \text { health = health expenditure - Proxy for human capital } \\
& \text { gross = gross capital formation - Proxy for physical capital, } \mathrm{K} \\
& \text { labour = participation of labour rate -Proxy for labour, } \mathrm{L} \\
& \mu=\text { error term }
\end{aligned}
$$

In the context of panel co-integration, the relationship between GDP per capita, education expenditure, health expenditure, gross capital creation, and labour rate would be examined. First, the variables are evaluated using the panel unit root tests PP- Fisher Chi-square and Hadri. Second, the long-run relationship between the variables would be examined using the Pedroni Co-integration test, the Kao Residual Co-Integration test, and the Johansen Fisher Cointegration test. Thirdly, the co-integration coefficients would be estimated using Panel FMOLS. Finally, granger causality is applied to decide if the variables are bidirectional or unidirectional. Figure 1 depicts the methodology's flow. 


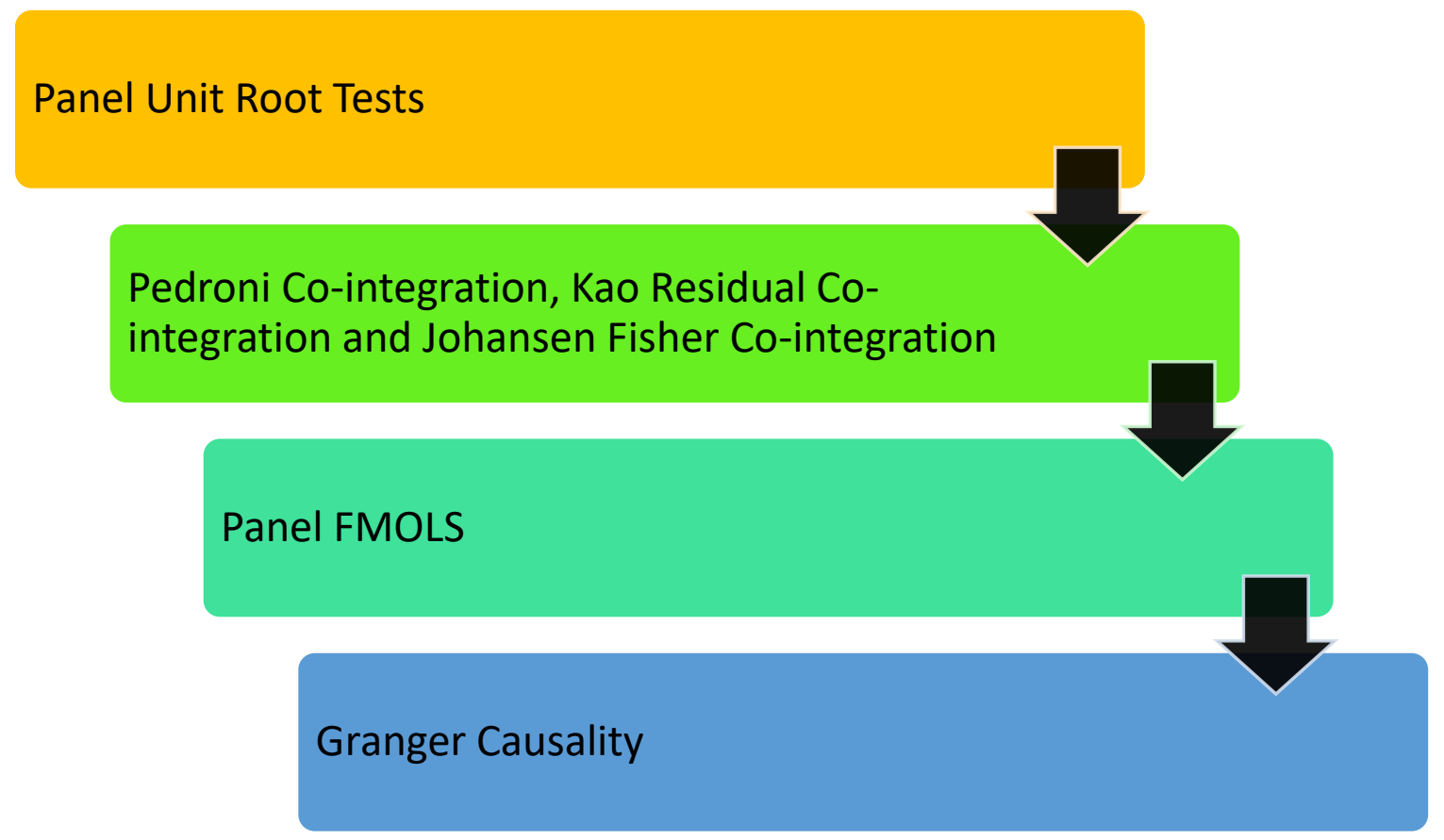

Figure 1: Flow of the Methodology

\section{Empirical Result \\ Panel Unit Root Tests}

Panel unit root tests are the preliminary tests that must be performed before leading to the empirical analysis to ensure that the variables are stationary. This is due to the fact that if the variables used in this research are stationary, then regression analysis can be used to examine the relationship between the variables. Even so, if the variables are not stationary, the issue of fake regression arises. As a result, the variables must be tested as part of the panel unit root tests. PP-Fisher Chi-square and Hadri are used to examine the existence of the unit root in panel series.

The panel unit root tests yielded the following results, as shown in Table 2. Overall, it demonstrates that the set of variables is stationary at first difference, I (1). We rejected the null hypothesis and accepted the alternative hypothesis because the variables are not stationary at level, I (0). This describes why the variables are stationary at first difference and why panel data does not have a unit root. 
Table 2 Panel Unit Root Tests

\begin{tabular}{llll}
\hline & & LEVEL, I (0) & FIRST DIFFERENCE, I (1) \\
\cline { 3 - 4 } Variables & Panel Unit Root & Intercept and Trend & Intercept \\
\hline GDP & Pests & & \\
& PP-Fisher Chi- & 12.880 & $34.201 * * *$ \\
& square & $3.975^{* * *}$ & 1.218 \\
\hline EDUCATION & Hadri & & $37.786^{* * *}$ \\
& PP-Fisher Chi- & 4.570 & 1.110 \\
& square & $3.588^{* * *}$ & \\
\hline HEALTH & Hadri & & $63.330^{* * *}$ \\
& PP-Fisher Chi- & $21.015^{* * *}$ & 1.176 \\
\hline GROSS & square & $1.746^{* * *}$ & $39.636^{* * *}$ \\
CAPITAL & Hadri & & 1.176 \\
FORMATION & PP-Fisher Chi- & 15.716 & \\
\hline LABOR & Square & $3.713^{* * *}$ & $48.292^{* * *}$ \\
& Padri & & 1.940 \\
& PP-Fisher Chi- & 7.625 & \\
\hline$* * * * *$ & $3.498^{* * *}$ & \\
\hline
\end{tabular}

$*, * *, * * *$ indicates $10 \%, 5 \%, 1 \%$ significance level respectively. For PP-Fisher Chi-square; $\mathrm{H}_{\mathrm{o}}=$ Panel data has unit root (non-stationary), $\mathrm{HI}=$ Panel data has no unit root (stationary). For Hadri; $\mathrm{H}_{\mathrm{o}}=$ Panel data has no unit root (stationary), $\mathrm{HI}_{\mathrm{I}}=$ Panel data has unit root (nonstationary).

\section{Panel Co-integration}

One of the aims of this paper is to see whether there is some co-integration between the dependent variable (GDP per capita) and the independent variables (education expenditure, health expenditure, gross capital formation and labour). Pedroni Panel Co-integration, Kao Residual Co-integration test, and Johansen Fisher Panel Co-integration test are used in this paper to achieve the aim. The results of the Pedroni Panel Co-integration, Kao Residual Cointegration, and Johansen Fisher Panel Co-integration tests are shown in Tables 3, 4, and 5 below:

The Pedroni co-integration test results are shown in Table 3 below. The panel PP-statistic, panel ADF-statistic, group PP-statistic, and group ADF-statistic all rejected the null hypothesis at the $5 \%$ significance level using the fixed effects model. Panel PP-statistic, panel ADFstatistic, group PP-statistic, and group ADF-statistic all rejected the null hypothesis at the $1 \%$ significance level in the fixed effects and trend models. As a result, these findings indicate that the variables co-integrate over time. 
Table 3 Results of Pedroni Panel Co-integration test

\begin{tabular}{|l|l|l|}
\hline \multicolumn{1}{|c|}{ Test } & \multicolumn{1}{c|}{ Intercept } & \multicolumn{1}{c|}{ Intercept and Trend } \\
\hline Panel v-Statistic & -0.233 & 0.844 \\
\hline Panel rho-Statistic & 0.313 & 0.363 \\
\hline Panel PP-Statistic & $-1.779^{* *}$ & $-2.808^{* * *}$ \\
\hline Panel ADF-Statistic & $-1.793^{* *}$ & $-2.816^{* * *}$ \\
\hline Group rho-Statistic & 1.117 & 1.156 \\
\hline Group PP-Statistic & $-1.867^{* *}$ & $-2.610^{* * *}$ \\
\hline Group ADF-Statistic & $-1.775^{* *}$ & $-2.583^{* * *}$ \\
\hline
\end{tabular}

$*, * *, * * *$ indicates $10 \%, 5 \%, 1 \%$ significance level respectively. $\mathrm{H}_{\mathrm{o}}=$ Panel data has no cointegration, $\mathrm{HI}=$ Panel data has co-integration.

The results of the Kao Residual Co-integration test are shown in Table 4. It demonstrates that the probability value is less than $1 \%$ when we reject the null hypothesis. As a result, it demonstrates that the variables are co-integrated and have a long-run relationship.

Table 4 Kao Residual Co-integration Test

\begin{tabular}{lll}
\hline \hline & t-Statistic & Prob. \\
\cline { 2 - 3 } ADF & $-4.320551^{* * *}$ & 0.0000 \\
\hline \hline Residual variance & 0.006862 & \\
HAC variance & 0.005708 & \\
\hline \hline
\end{tabular}

$*, * *, * * *$ indicates $10 \%, 5 \%, 1 \%$ significance level respectively. $\mathrm{H}_{\mathrm{o}}=$ Panel data has no cointegration, $\mathrm{HI}=$ Panel data has co-integration.

The results of the Johansen Fisher Co-integration test are shown in Table 5. The results show that the Fisher trace test and Fisher max-eigen test have a long run relationship for at least four variables. Hence, Pedroni Panel Co-integration, Kao Residual Co-integration, and Johansen Fisher Panel Co-integration all produce similar results, indicating a long-run relationship between the dependent and independent variables. Therefore, it is necessary to estimate the co-integration coefficient for the variables estimated in the panel co-integration. 
Table 5 Johansen Fisher Co-integration Test

\begin{tabular}{lllll}
\hline \hline $\begin{array}{l}\text { Hypothesized } \\
\text { No. of CE(s) }\end{array}$ & $\begin{array}{l}\text { Fisher Stat. }^{{ }^{1}} \\
\text { (from trace test) }\end{array}$ & Prob. & $\begin{array}{l}\text { Fisher Stat. } \\
\text { (from max-eigen test) }\end{array}$ & Prob. \\
\hline \hline None & $153.2^{* * *}$ & 0.0000 & $97.14^{* * *}$ & 0.0000 \\
At most 1 & $78.09^{* * *}$ & 0.0000 & $56.42^{* * *}$ & 0.0000 \\
At most 2 & $33.51^{* * *}$ & 0.0000 & $24.14^{* * *}$ & 0.0022 \\
At most 3 & $16.73^{* *}$ & 0.0331 & 11.79 & 0.1610 \\
At most 4 & $18.18^{* *}$ & 0.0199 & $18.18^{* *}$ & 0.0199 \\
\hline \hline
\end{tabular}

$*, * *, * * *$ indicates $10 \%, 5 \%, 1 \%$ significance level respectively. $\mathrm{H}_{\mathrm{o}}=$ Panel data has no cointegration, $\mathrm{HI}=$ Panel data has co-integration. ${ }^{1}$ Probabilities are computed using asymptotic chi-square distribution.

\section{Estimation of Panel co-integration Coefficient}

After estimating the co-integration using Pedroni Co-integration, Kao Residual Co-integration, and the Johansen Fisher Panel Co-integration test, the long-term co-integration coefficients must be estimated. Since the variables have a long run relationship, panel completely updated ordinary least squares (FMOLS) methods can be used to calculate the coefficient value of cointegration. The FMOLS approach is used in estimation primarily because it corrects the autocorrelation and endogeneity problems.

The results of regressing the panel FMOLS are shown in Table 6. According to the panel FMOLS results, both health expenditure and gross capital formation have a positive impact on GDP per capita, and both variables are significant. Education and labour costs, on the other hand, are insignificant.

Table 6 Panel co-integration coefficients

\begin{tabular}{ll}
\hline Variables & Panel FMOLS \\
\hline Education & $0.1163(1.358)$ \\
\hline Health & $0.4581^{* * *}(4.028)$ \\
\hline Gross capital formation & $0.665^{* * *}(18.711)$ \\
\hline Labour & $-1.160(-1.334)$ \\
\hline$*, * *, * * *$ indicates $10 \%, 5 \%, 1 \%$ significance level respectively, () indicate t-statistics value
\end{tabular}

\section{Panel Granger Causality}

The panel co-integration tests only show that the variables are co-integrated in the long run, but they do not provide information about the direction of the relationship. Therefore, panel granger causality is used to determine the direction of the relationship in this study. The Granger causality test results are shown in Table 7 . The granger causality test results indicate that there is a bidirectional causality relationship between education spending and GDP per capita. Furthermore, there is a unidirectional causality direction from health to GDP per capita, GDP per capita to gross capital formation, health expenditure to education expenditure, labour to health expenditure, health to gross capital formation, and gross capital formation to secondary school enrolment. 
Table 7 Granger Causality

\begin{tabular}{lll}
\hline \hline Null Hypothesis: & F-Statistic & Prob. \\
\hline \hline LEDUCATION does not Granger Cause LGDP & $4.37149^{* *}$ & 0.0164 \\
LGDP does not Granger Cause LEDUCATION & $3.20929^{* *}$ & 0.0467 \\
\hline \hline LGROSS does not Granger Cause LGDP & 1.90794 & 0.1564 \\
LGDP does not Granger Cause LGROSS & $6.65245^{* * *} 0.0023$ \\
\hline \hline LHEALTH does not Granger Cause LGDP & $6.66173^{* * *} 0.0023$ \\
LGDP does not Granger Cause LHEALTH & 0.05514 & 0.9464 \\
\hline \hline LLABOR does not Granger Cause LGDP & 2.06207 & 0.1352 \\
LGDP does not Granger Cause LLABOR & 0.12941 & 0.8788 \\
\hline \hline LGROSS does not Granger Cause LEDUCATION & 1.00528 & 0.3714 \\
LEDUCATION does not Granger Cause LGROSS & 1.30950 & 0.2768 \\
\hline \hline LHEALTH does not Granger Cause LEDUCATION & $2.99221^{*}$ & 0.0569 \\
LEDUCATION does not Granger Cause LHEALTH & 0.99062 & 0.3767 \\
\hline \hline LLABOR does not Granger Cause LEDUCATION & 0.00261 & 0.9974 \\
LEDUCATION does not Granger Cause LLABOR & 2.03768 & 0.1383 \\
\hline \hline LHEALTH does not Granger Cause LGROSS & $3.66153^{* * *} 0.0053$ \\
LGROSS does not Granger Cause LHEALTH & 0.23005 & 0.7951 \\
\hline \hline LLABOR does not Granger Cause LGROSS & 0.32219 & 0.7257 \\
LGROSS does not Granger Cause LLABOR & 0.43309 & 0.6503 \\
\hline \hline LLABOR does not Granger Cause LHEALTH & 3.69388 & 0.0749 \\
\hline \hline
\end{tabular}

$*, * *, * * *$ indicates $10 \%, 5 \%, 1 \%$ significance level, respectively.

\section{Conclusion and Implication}

The relationship between GDP per capita, human capital expenditures (education and health spending), gross capital development (as a proxy for physical capital, K), and labour participation rate (as a proxy of labour, $L$ ) is investigated in this paper. Yearly data on the selected variables (GDP per capita, education expenditure, health expenditure, and gross capital formation) and the 4-ASEAN countries, namely Indonesia, Malaysia, the Philippines, and Thailand, are used. The panel co-integration is used to estimate the series' co-integration. The outcome is consistent with all panel co-integration tests that have been performed (Pedroni Co-Integration Test, Kao Residual Co-Integration Test and Johansen Fisher Cointegration test). As a result, the panel FMOLS estimates the coefficient of co-integration, indicating that health spending and gross capital formation have a substantial effect on economic growth under panel FMOLS.

This research has several policy implications. The study's findings are expected to benefit policymakers and the government. Policymakers should consider policy restructuring 
in education, health, and training by looking at excellent educational models implemented by other developed countries such as Singapore, South Korea, Japan, and the United Kingdom. To promote lifelong learning among Malaysian people (Malaysia 2010), the labour force with a low education level should take the initiative to further their education. Next, from the standpoint of the economy, it indicates that human capital investments would influence economic development. Given its importance to the economy, any fluctuation in the production of human capital stock could hinder economic growth.

\section{References}

Agbola, F. W. (2013). Does human capital constrain the impact of foreign direct investment and remittances on economic growth in Ghana? Applied Economics, 45(19), 28532862.

Atuahene, S. A., Yusheng, K., \& Bentum-Micah, G. (2020). Health expenditure, CO2 emissions, and economic growth: China vs India. Preprints. doi: 10.20944/preprints202009. 0384.v1.

Atuma, E., Stephen, I. O., \& Paul, N. N. (2017). Domestic investment, capital formation and economic growth in Nigeria. International Journal of Research in Social Sciences. 7(2). 41-65.

Bakare, A. A., \& Olubokun, S. (2011). Health care expenditure and economic growth in Nigeria: An empirical study. Journal of Emerging Trends in Economics and Management Sciences, 2(2), 83-87.

Boachie, M. K. (2017). Health and economic growth in Ghana: an empirical investigation. Fudan Journal of the Humanities and Social Sciences. 10. 253-265.

Dzubaidi, R. A. M., Rahmah, I., \& Tamat, S. (2013). Peranan perbelanjaan kerajaan terhadap pembangunan manusia dan pertumbuhan ekonomi. Persidangan Kebangsaan Ekonomi Malaysia, 872-879.

Elmi, Z. M., \& Sadeghi, S. (2012). Health care expenditures and economic growth in developing countries: panel co-integration and causality. Middle-East Journal of Scientific Research, 12(1), 88-91.

Karambakuwa, R. T., Ncwadi, R., \& Phiri, A. (2020). The human capital-economic growth nexus in SSA countries: what can strengthen the relationship? International Journal of Social Economics. 47(9). 1143-1159.

Maitra, B. (2016). Investment in human capital and economic growth in Singapore. Global Business Review. 17(2), 425-437.

Mat, N. A., Mansur, K., \& Mahmud, R. (2015). The relationship between human capital investment and economic development in Sabah. Malaysian Journal of Business and Economics (MJBE), 2(1).

Mekdad, Y., Dahmani, A., \& Louaj, M. (2014). Public spending on education and economic growth in Algeria: Causality test. International Journal of Business and Management, 2(3), 55.

Mushtaq, A., Mohsin, A., \& Zaman, K. (2013). Effects of health on changing labor force participation in Pakistan. SpringerPlus, 2(1), 610.

Neeliah, H., \& Seetanah, B. (2016). Does human capital contribute to economic growth in Mauritius?. European Journal of Training and Development.

Onyinye, G. O., Idenyi, O. S., \& Ifeyinwa, A. C. (2017). Effect of capital formation on economic growth in Nigeria. Asian Journal of Economics, Business and Accounting. 5(1), 1-16. 
Osiobe, E. U. (2020). Human capital, capital stock formation and economic growth: a panel granger causality analysis. Journal of Economics and Business. 3(2), 569-582.

Oyedokun, G. E. (2018). Human capital formation and economic growth in Nigeria. International Journal of Finance \& Banking Studies. 7(3), 44-65.

Rehman, M. A., Ghaffar, S., Shahzadi, K., \& Ghazanfar, R. (2020). Human capital formation and economic growth in emerging asia: empirical evidence using panel data. Review of Applied Management and Social Sciences. 3(2), 205-212.

Robert, L. (1988). On the mechanics of economic development. Journal of monetary economics.

Romer, P. (1990). Are nonconvexities important for understanding growth? (No. w3271). National Bureau of Economic Research.

Sarpong, B., Amponsah, E. N., \& Owoo, N. S. (2018). Health and economic growth nexus: evidence from selected sub-saharan african (SSA) countries. Global Business Review. 21(2), 328-347.

Shahid, M. (2014). Impact of labour force participation on economic growth in Pakistan. Journal of Economics and Sustainable Development, 5(11), 89-93.

Sharma, V., \& Mittal, A. (2019). Fiscal deficit, capital formation, and economic growth in India: a nonlinear ARDL model. Decision, 46, 353-363.

Siddiqui, A., \& Rehman, A. (2017). The human capital and economic growth nexus: in East and South Asia. Applied Economics, 49(28), 2697-2710.

Tatoglu, F. Y. (2011). The relationships between human capital investment and economic growth: A Panel Error Correction Model. Journal of Economic and Social Research, 13(1), 77.

Ugochukwu, U. S., \& Chinyere, U. P. (2013). The impact of capital formation on the growth of Nigerian economy. Research journal of finance and accounting, 4(9), 36-42.

Uneze, E. (2013). The relation between capital formation and economic growth: evidence from sub-Saharan African countries. Journal of Economic Policy Reform, 16(3), 272286.

Uzawa, H. (1965). Optimum technical change in an aggregative model of economic growth. International economic review, 6(1), 18-31.

World Bank. (1993). World Development Report 1993: Investing in Health, Volume1. World Bank.

World Bank Group. (2016). World development report 2016: digital dividends. World Bank Publications.

Yang, X. (2020). Health expenditure, human capital, and economic growth: an empirical study of developing countries. International Journal of Health Economics and Management. 20, 163-176.

Yildirim, S., Yildrim, D. C., \& Caliskan, H. (2020). The influence of health on economic growth from the perspective of sustainable development: a case of OECD countries. World Journal of Entrepreneurship, Management and Sustainable Development, 16(3), 181194. 